\title{
CHRZEŚCIJAŃSKIE MAŁŻONKI SUŁTANÓW TURECKICH MAŁŻEŃSTWA POLITYCZNE W IMPERIUM OSMAŃSKIM XIV I XV WIEKU
}

\author{
ILONA CZAMAŃSKA
}

\begin{abstract}
Ilona Czamańska, Chrześcijańskie matżonki sułtanów tureckich. Mał̇eństwa polityczne w Imperium Osmańskim XIV i XV wieku (Christian wives of the Turkish sultans. Marriages political in the Ottoman Empire $14^{\text {th }}$ and $15^{\text {th }}$ centuries).
\end{abstract}

Balcanica Posnaniensia. Acta et studia, XX, Poznań 2013, Wydawnictwo Instytutu Historii UAM, pp. 47-63, ISBN 978-83-63047-36-1, ISSN 0239-4278. Polish text with a summary in English.

Ilona Czamańska, Uniwersytet im. Adama Mickiewicza, Instytut Historii, ul. Św. Marcin 78, 61-809 Poznań.

Islam, dopuszczający możliwość posiadania jednocześnie czterech żon, dawał władcom osmańskim większe szanse uprawiania polityki poprzez związki rodzinne, niż władcom chrześcijańskim. Element ten był dość często przez nich wykorzystywany, zwłaszcza w pierwszych dwóch wiekach istnienia państwa Turków Osmańskich. Badanie rzeczywistego charakteru i funkcji małżeństw pierwszych władców osmańskich z przedstawicielkami innych rodzin panujących, w szczególności chrześcijankami, nie jest sprawą prostą. Po pierwsze źródła na ten temat są bardzo skąpe i pochodzą często z późniejszego okresu, na ogół z czasów, gdy zjawisko to już nie występowało, a zastapiła je całkowicie instytucja rozbudowanego haremu sułtańskiego ${ }^{1}$. Po dru-

${ }^{1}$ Określenia harem sultana używamy tutaj i w całym artykule w znaczeniu potocznym, oznaczającym wydzieloną dla kobiet część pałacu władcy muzułmańskiego wraz jej mieszkankami, tworzącymi zorganizowaną hierarchiczną instytucję. Wypada jednak wspomnieć, że w rozumieniu islamu wszystkie kobiety znajdujące się pod opieką mężczyzny stanowiły jego harem. Ich status bywał różny (matka, oficjalne żony, niezamężne siostry, córki, konkubiny, zakładniczki, służące, niewolnice). Nie wszystkie jednak kobiety stanowiące harem pierwszych władców osmańskich, zamieszkiwały w haremie - instytucji i podlegały wszystkim rygorom wspólnotowego życia. W takim sensie rozumieć należy podawane poniżej informacje, na temat poszczególnych małżonek, że nie były włączone do haremu. Niewątpliwie też harem sułtański w sensie instytucjonalnym ewoluował i w XIV czy na początku XV wieku musiał wyglądać inaczej niż w XVI-XVIII wieku, a dopiero z tego ostatniego okresu pochodzą bardziej dokładne informacje na temat jego organizacji. Harem pierwszych władców osmańskich był w większym stopniu instytucją rodzinna. Na temat haremu zob. L. P. Peirce, The Imperial Harem. Women and Sovereingty in the Ottoman Empire, New York - Oxford 1993. Autorka jednak zdaje się nazbyt często w odniesieniu do tej wczesnej 
gie wokół tych małżeństw narosła legenda, naznaczona symptomem ofiary, która zakorzeniła się bardzo silnie także w naukowej literaturze historycznej. Podjęcie, mimo tych trudności, próby wyświetlenia zjawiska kontraktowych małżeństw politycznych jest istotne nie tylko ze względu na ich rolę w kształtowaniu sceny politycznej, ale także na ich rolę w kształtowaniu się relacji międzykulturowych.

Zaczęły się one już w początkowym okresie rozwoju państwa osmańskiego. Emir Orchan (1326-1361) miał aż trzy żony pochodzenia chrześcijańskiego ${ }^{2}$. Jeszcze za życia ojca, poślubił on Holofernę (Holofirę), córkę Michała - bizantyńskiego zarządcy Belokomy (obecnie Bilecik) i władcy Yarhisar. Według legendy piękna Holoferna, która w 1299 roku wychodziła za mąż, miała zostać zabrana prosto sprzed ołtarza przez Osmana i oddana za żonę dwunastoletniemu wówczas Orchanowi. Niewiadomo, jak to było naprawdę, niewątpliwie jednak poślubienie Holoferny przez młodego następcę Osmana miało uprawomocnić aneksję terytoriów należących do jej ojca. Pamiętać należy, że beylik Osmana był wówczas niewielkim państwem, zaledwie wyzwalającym się spod władzy seldżuckich ilchanów, i rozpoczynał dopiero swą ekspansję. Nawiązanie stosunków rodzinnych umożliwiło ojcu Holoferny funkcjonowanie w ramach nowego państwa. Wiadomo, że przeszedł on na islam i do śmierci sprawował władzę na swych terytoriach. Do realnego zawarcia małżeństwa Orchana i Holoferny, która po przyjęciu islamu otrzymała imię Nilüfer Hatun (Pani Lilia Wodna), musiało dojść jednak raczej nie wcześniej niż w połowie drugiego dziesięciolecia XIV wieku. Wskazywałyby na to daty urodzin ich dzieci: Sulejmana (jeśli istotnie był jej synem, bo to nie jest pewne) - 1316, Sultana - 1324 i Murada - $1326^{3}$. Małżeństwo to zapewniło Orchanowi współpracę polityczną teścia, który zresztą też przeszedł na islam i został, jako jego wasal, zarządcą okręgu czasowej stolicy - Yarhisar, a więc bardzo bliskim i z pewnością zaufanym współpracownikiem. Holoferna - Nilüfer Hatun również przyjęła islam ${ }^{4}$. Miała ogromne wpływy w państwie osmańskim, zwłaszcza po tym, jak w 1360 roku przejął władzę jej syn - Murad I. Wprawdzie szczyt wpływów matek sułtańskich (walide sultan) miał nastąpić później, niemniej jednak już wówczas traktowane były z najwyższą powagą i szacunkiem.

Najbardziej zagadkową spośród żon Orchana jest Asporcza. Niewiele o niej wiemy. Uchodzi ona powszechnie za córkę cesarza bizantyńskiego Andronika III, co jednak było fizyczną niemożliwością. Andronik III, urodzony w roku 1298, musiałby

epoki odwoływać się do przykładów z czasów późniejszych. Nowe zupełnie podejście do tematu prezentuje wydana po raz pierwszy w 1995 roku praca Ahmeda Akgündüza, İslâm hukukunda kölelik-câriyelik müessesesi ve Osmanll'da harem, który wyraźnie wiąże ukształtowanie się haremu sułtańskiego, jako instytucji, z budową pałacu Topkapi w Stambule. Praca niestety ukazała się wyłącznie w języku tureckim.

${ }^{2}$ A. Akgündüz, S. Oztürk, Ottoman history: Misperceptions and Truths, Istanbul 2011, s. 47. Autorzy ci wymieniają cztery małżonki Orchana, które miały być poślubiane w następującej kolejności: Nilüfer Hatun, Asporça Hatun, Teodora Hatun i Eftandise Hatun, córka Mahmuda Alpa. Trzy pierwsze były chrześcijankami, jednak tylko Teodora pozostała przy religii chrześcijańskiej.

${ }^{3}$ Münir Atalar, Osmanli padişahlari, „Ankara Ünv. İlâhiyat Fakültesi İslâm İlimleri Enstitüsü Dergisi”, Ankara 1981, C XXIV, s. 430 - http://dergiler.ankara.edu.tr (dostęp 1.06.2011). Według A. Akgündüza i S. Oztürka jeden z synów miał na imię nie Sultan a Kasem - op. cit. s. 47.

${ }^{4}$ A. Akgündüz, S. Oztürk, Ottoman history: Misperceptions and Truths, s. 43. 
ją spłodzić w kołysce, albo najlepiej jeszcze przed swym urodzeniem, niewątpliwie bowiem była już małżonką syna Osmana w roku 1310, kiedy to urodził się ich syn - Ibrahim ${ }^{5}$. Zastanawiające też, że o małżeństwie cesarskiej córki milczą zupełnie kroniki bizantyńskie. Przeszła na islam, co raczej niespotykane wśród bizantyńskich księżniczek, nawet nie znamy jej chrześcijańskiego imienia. Kondycja Bizancjum, mimo problemów, nie była w tym czasie tak zła, by którykolwiek cesarz mógł wydać córkę za mało jeszcze znaczącego syna tureckiego beja i nawet nie zabezpieczyć jej odpowiedniej pozycji i wyznania. Wszystko to skłania do postawienia w wątpliwość cesarskiego pochodzenia Asporczy.

Kolejną, trzecią małżonką Orchana była córka antycesarza bizantyńskiego Jana VI Kantakuzena, którą poślubił w roku 1346. Małżeństwo to miało umocnić przymierze Jana VI z emirem Orchanem. Powinowactwo rodzinne traktowano bardzo poważnie. Sojusz polityczny utrzymał się do czasu abdykacji Kantakuzena w 1354 roku, a nawet dłużej, gdyż później Orchan wielokrotnie udzielał pomocy zbrojnej synowi Jana Kantakuzena - Maciejowi.

Mimo małżeństwa $\mathrm{z}$ islamskim władcą, Teodora pozostała chrześcijanką. Jako najmłodsza z małżonek niewątpliwie wywierała wpływ na Orchana, któremu urodziła przynajmniej jednego syna Halila. Po abdykacji Jana VI Kantakuzena, pojawiła się szansa, że syn Teodory umożliwi pokój, a może i sojusz pomiędzy cesarzem bizantyńskim Janem V a Orchanem. Sprawił to pewien incydent, który wydarzył się w 1357 roku na Morzu Czarnym. Dziesięcioletni Halil, który otrzymał już swój nadział wokół Izmitu i Gemliku, został wzięty do niewoli przez korsarzy greckich czy genueńskich w czasie wyprawy na ryby. Porywacze odwieźli go do Fokei nad Morzem Egejskim, której grecki zarządca Kalopat zatrzymał go i zażądał okupu w wysokości 100000 solidów. Władca turecki zwrócił się wówczas do cesarza bizantyńskiego z prośbą o interwencję w tej sprawie. Jan V zapłacił żądany okup i Halil przywieziony został do Konstantynopola. Jak to się często zdarzało w tej epoce, cesarz zaaranżował małżeństwo Halila ze swą również dziesięcioletnią córką Ireną, notabene po matce bliską kuzynką tureckiego książątka. Oczywiście miała to być inwestycja polityczna. Cesarz podobno osobiście odwiózł młodą parę do Izmitu i przekazał Orchanowi z życzeniem, aby uczynił Halila swoim następcą ${ }^{6}$. Szybka śmierć Orchana w marcu 1361 roku uniemożliwiła realizację tego projektu, szansę w walce o władzę mogli mieć jedynie jego starsi i bardziej doświadczeni synowie. W wyniku długotrwałej wojny domowej i fizycznej likwidacji wszystkich swoich braci, w tym również Halila, zwyciężył ostatecznie Murad pochodzący z małżeństwa Orchana z Nilüfer Hatun ${ }^{7}$. Teodora, po śmierci męża i utracie syna, powróciła do Bizancjum.

\footnotetext{
${ }^{5}$ Münir Atalar, Osmanli padişahlari, s. 430.

${ }^{6}$ К. Имбер, Османската империја 1300-1481, Скопје 2002, s. 31. Aurel Decei pisze, że Halil był ulubionym synem Orchana, przewidywanym na jego następcę - A. Decei, Istoria Imperiului Otoman pînă la 1656, Bucureşti 1978, s. 38.

${ }^{7}$ F. Babinger, Nilufer Khatun, w: The Encyklopedia of Islam - New edition, t. VIII, red. P. Bearman, Th. Bianquis, C.E. Bosworth, E. van Donzel and W. P. Heinrichs, Leiden 1995, s. 43.
} 
Murad I kontynuował tradycję ojca i również budował sojusze z chrześcijanami umacniając je małżeństwami. Według A. Akgündüza i S. Oztürka jego małżonkami były: Gülçiçek Hatun, Maria Tamara Hatun, Melek Paşa Hatun, i dwie małżonki nieznane z imienia. Dwie małżonki miały pochodzić z Bułgarii: Maria Tamara i druga nieznana $z$ imienia ${ }^{8}$. Na temat tej drugiej nie mamy właściwie żadnej wiadomości, najprawdopodobniej nie została poślubiona w sposób formalny na zasadzie kontraktu. Więcej wiadomo natomiast na temat Marii Tamary, zwanej też Kerą Tamarą. W 1371 roku serbscy Mrnjavčevicie przystappili do budowy sojuszu antytureckiego, czyniąc też prawdopodobnie zabiegi o włączenie do niego Bułgarii, w której władzę, po śmierci Iwana Aleksandra, przejął jego najmłodszy syn - Iwan Szyszman. Mimo faktycznego rozpadu Bułgaria mogła jeszcze wydawać się dość silnym państwem, dlatego też wyeliminowanie jej z ewentualnego sojuszu antytureckiego musiało być dla Murada istotne. Liczne źródła odnotowały, że po śmierci Iwana Aleksandra (zm. 2302 1371), do jego następcy, Iwana Szyszmana, przybyło poselstwo tureckie z prośbą o rękę jego siostry, Kery Tamary, dla Murada $\mathrm{I}^{9}$. Car bułgarski początkowo odmówił, dopiero po pewnym czasie zgodził się na to małżeństwo i proponowany układ pokojowy ${ }^{10}$.

Kera Tamara była córką cara Iwana Aleksandra z pierwszego małżeństwa z Teodorą I, córką hospodara wołoskiego Basaraba $\mathrm{I}^{11}$. Urodziła się prawdopodobnie ok. 1340 roku, bowiem w roku 1355 była już żoną bułgarskiego wielmoży, despoty Konstantyna. Małżonka Kery Tamary nie należy mylić z despotą Konstantynem Dragašem, jak to dość często bywa w literaturze. W 1371 roku Kera Tamara liczyła sobie około trzydziestu lat i była już wdową. Mimo że nie była już pierwszej młodości była podobno bardzo urodziwa. Murad także nie był wówczas młodzieńcem, miał już bowiem 45 lat. Nie ulega zresztą wątpliwości, że cel tego małżeństwa był przede wszystkim polityczny ${ }^{12}$. Najprawdopodobniej nie było też z tego małżeństwa dzieci, a przynajmniej żadne nie pozostało dłużej przy życiu.

Po zawarciu małżeństwa z Muradem, Kera Tamara zachowała religię chrześcijańska. W pomianniku cerkwi bułgarskiej, tzw. Boriłowym synodyku, zapisana została: „Wieczna pamięć Kery Tamary, córki cara Iwana Aleksandra, wielkiej pani małżonki wielkiego emira Murada, która została mu oddana dla bułgarskiego rodu. A ta, jak odeszła tam, zachowała prawosławną wiarę, oswobodziła swój ród, żyła dobrze i prawowiernie opuściła ten świat.” (tłum. I. C.) ${ }^{13}$. Na podstawie kolejności zapisów w tymże źródle należy wnioskować, że carewna bułgarska zmarła wcześniej od swego męża, wcześniej niż pierwsza małżonka Iwana Szyszmana, a więc najpóźniej około połowy lat osiemdziesiątych XIV stulecia. Pochowana została w grobowcu rodziny osmańskiej w Brusie, jednak bez atrybutów tradycyjnych dla wyznawców islamu.

${ }^{8}$ A. Akgündüz, S. Oztürk, Ottoman history: Misperceptions and Truths, s. 51.

${ }^{9}$ L. Chalcocondiles mylnie twierdzi, że była to córka Szyszmana z małżeństwa z Żydówką L. Chalcocondil, Expuneri istorice, ed. V. Grecu, București 1958, s. 41.

${ }^{10}$ И. Тютюиджиев, Българската анонимна хроника, от XV век, Велико Търново 1992, s. 81.

${ }^{11}$ И. Божилов, Асеневии(1186-1460) генеалогия и просопография, София 1985, s. 151 і 214.

12 Tamże, s. 214-218.

${ }^{13}$ И. Дуйчевъ, Изъ старата българска книжнина, кн. 2, София b. d. [1944?], s. 163. 
Polityczne małżeństwa z chrześcijankami kontynuował również Bajezid I. Gdy objął tron miał on już kilka małżonek pochodzących z Azji Mniejszej ${ }^{14}$, poślubienie kolejnej, Serbki, nie było prawdopodobnie jego inicjatywą. Po bitwie na Kosowym Polu (15 06 1389) sytuacja polityczna Serbii stała się bardzo skomplikowana, przede wszystkim ze względu na to, że książę Lazar nie miał dorosłych synów, a wielu było pretendentów do schedy po Nemaniciach. Uważający się za suzerena Serbii Zygmunt Luksemburczyk poparł na tron serbski Vuka Brankovicia. Przeciwstawiła się temu energiczna małżonka Lazara, Milica, która podjęła walkę o tron dla swoich nieletnich synów. Nie jesteśmy w stanie z całą pewnością powiedzieć, czy poparcie węgierskie dla Vuka Brankovicia było reakcją na poddanie się Milicy następcy Murada I, Bajezidowi I, czy też odwrotnie. W każdym razie jesienią 1389 roku wkroczyła do Serbii armia węgierska, a Milica udała się na dwór sułtana Bajezida, by prosić go o pokój i przymierze, oferując mu zarazem rękę swej najmłodszej córki Olivery. Decyzja wydania za mąż serbskiej prawosławnej księżniczki za muzułmańskiego emira podjęta została z pełną akceptacją serbskiego patriarchy i całego zgromadzenia najwyższych serbskich duchownych. ,,aby zostało uratowane chrześcijańskie stado od wilków, które na niego czyhały" - pisał Konstanty Filozof ${ }^{15}$. Układ pokojowy z Turkami oraz prawdopodobnie jednocześnie małżeństwo Olivery zawarte zostały w połowie 1390 roku $^{16}$.

Z politycznego punktu widzenia małżeństwo to spełniło swoją rolę. Wbrew dość często powtarzanym stereotypowym poglądom o upadku państwa serbskiego po bitwie kosowskiej, przez dwanaście lat trwania małżeństwa Olivery z Bajezidem pozycja Serbii wobec Turcji nie uległa istotnej zmianie i nic nie wskazuje, by miała to być wyłącznie pozycja podporządkowanego wasala. Obydwa państwa związane były ścisłym sojuszem polityczno-wojskowym i obydwa z niego korzystały. Przy pomocy tureckiej Stefan Lazarević podporządkowywał sobie przeciwników politycznych i powiększał terytorium swego państwa, przyłączając do niego m. in. Kosowo. Wojska serbskie udzielały Bajezidowi pomocy przeciw rozmaitym wrogom, także przeciw chrześcijanom i nie była to pomoc pozorowana. Niewątpliwie rodzinny związek miał w tych działaniach znaczenie istotne.

14 Według A. Akgündüza i S. Oztürka Bayezid I miał łącznie 5 żon: Germyanli Devlet Şah Hatun, Devlet Hatun, Hafsa Hatun, Sultan Hatun i Maria (Olivera, Despina) Hatun - A. Akgündüz, S. Oztürk, Ottoman history: Misperceptions and Truths, s. 69.

15 ,да би било спасено христоименито стадо од вукова, који су га клали” - Константин Филозоф, Повест о словима (Сказаније о писменех) - Житије деспота Стефана Лазаревића, Стара српска књижевност у 24 књиге, књига 11, прилагођавање на савремени српски језик Лазар Мирковић; редакција превода Гордана Јовановић; прир. Гордана Јовановић, Просвета - Српска књижевна задруга, Београд, 1989 - tekst dostępny na stronie http:/www.rastko.rs/knjizevnost/liturgicka/ konstantin-zitije_desp_stefana_c.html (dostęp: 3. 11. 2013).

16 Историја српског народа, т. 1, кн. 2, s. 49-50; J. V. A. Fine, The Late Medieval Balkans: A Critical Survey from the Late Twelfth Century to the Ottoman Conquest, Michigan 1987, s. 412. Według niektórych jednak małżeństwo Olivery i pokój miały zostać zawarte dopiero w 1391 r. - Н. Гиљен, О. Шарановић, С. Јовићевић Јов, Приниеза Оливера, заборављена српска Кнегиња, Београд 2009, s. 57. 
Sama Olivera, przynajmniej do czasu, też chyba nie mogła narzekać na swój los. Podobnie jak niegdyś Kera Tamara, małżonka Murada, została ceremonialnie poślubioną małżonką Bajezida ${ }^{17}$. Wiele wskazuje na to, że małżeństwo jej, mimo różnicy kultur, było udane. Małżonek pozwalał jej na kultywowanie religii chrześcijańskiej, nie mieszkała też stale w haremie. Miała własny dom i dwór, niewykluczone, że przynajmniej częściowo złożony również z chrześcijan. Najprawdopodobniej jednak, jako małżonka islamskiego władcy, przebywając w jego pałacu, musiała stosować się do obowiązujących tam zasad islamu ${ }^{18}$. Nie miała z Bajezidem synów, w każdym razie takich, którzy przeżyli na tyle długo, by zostali odnotowani w źródłach, wiadomo natomiast, że miała córkę.

Niektórzy przypisują jej duży wpływ na męża i sugerują że stała się ona jego ulubioną żoną. Chrześcijaństwo nie zabrania alkoholu, więc w jej domu było zapewne weselej, niż u innych małżonek Bajezida. Kronikarze tureccy mieli jej wręcz za złe, że rozpijała męża, co jednak podają w wątpliwość współcześni badacze, także tureccy ${ }^{19}$. Laonic Chalcocondyles, Konstanty z Ostrovicy, a za nimi Orbini i inni kronikarze europejscy odnotowali, że towarzyszyła mężowi w wyprawach wojennych i znajdowała się w obozie tureckim w czasie słynnej bitwy pod Ankarą w 1402 roku, podczas której razem z mężem trafiła do niewoli Tamerlana. Podobno Tamerlan, chcąc poniżyć swego jeńca, kazał jej usługiwać sobie przy stole i to w niekompletnym stroju, co miało spowodować samobójczą śmierć Bajezida, który na widok poniżenia swej małżonki i własnej bezsilności począł tłuc głową o żelazny pręt klatki, w której go trzymano ${ }^{20}$.

Informacje pochodzące z kronik europejskich budzą liczne wątpliwości współczesnych historyków, jako niezgodne ze źródłami wschodnimi. Kronikarz wypraw Tamerlana Ali Szaraf ad Din odnotował, że po zwycięstwie wojska mongolskie zdobyły Brusę i wzięły do niewoli małżonkę Bajezida z dwoma jego synami zamkniętą w wiejskim domu w Yenişeher, jak również córkę władcy Bagdadu Ahmeda Dżalayra, zaręczoną z synem Bajezida, Musą ${ }^{21}$. Ten sam kronikarz dalej pisze jednak, że synowie Bajezida i jego żona Destina, córka europejczyka Lausa, ze swoją córką i wszystkimi domownikami zostali później zaprezentowani Tamerlanowi ${ }^{22}$. Destina to niewątpliwie przekręcenie od Despina, czyli despotówna, a Laus to nikt inny jak Lazar.

17 Љ. Стојановић, Стари српски родослови и летописи, Ср. Карловци 1927, s. 136.

18 Tak chyba należy rozumieć tekst Szaraf ad Dina, który najpierw pisze, że małżonek pozwolił zachować jej wiarę, a zaraz potem, że w saraju Bajezida została zmuszona do przyjęcia islamu Histoire de Timur-Bec, connu sous le nom du grand Tamerlan, empereur des Mogols \& Tartares. En forme de journal historique de ses victoires \& conquêtes dans l'Asie \& dans l'Europe. Ecrite en persan par Cherefeddin Ali ... Tr. en françois par feu Monsieur Pétis de la Croix ... Avec des notes historiques, \& cartes geographiques, vol. 4, Paris, A Des Hayes 1722, s. 35. O tym, że pozostała chrześcijanką wiemy też zresztą z innych źródeł.

19 A. Akgündüz, S. Oztürk, Ottoman history: Misperceptions and Truths, s. 69-73.

${ }^{20}$ Pamiętniki janczara czyli Kronika turecka Konstantego z Ostrowicy, wyd. J. Łoś, Kraków 1912, s. 44; М. Орбин, Краљвевство Словена, Београд 1968, s. 103; L. Chalcocondyles, Expuneri istorice, trad. şi ed. V. Grecu, Bucureşti 1958, s. 107.

${ }^{21}$ Histoire de Timur-Bec, s. 26.

22 Tamże, s. 34-35. 
Wprawdzie ojciec Olivery nie nosił nigdy tytułu despoty, a i brat, Stefan Lazarević, otrzymał go od ówczesnego współcesarza Jana VII już po bitwie ankarskiej, niemniej jednak piszący w latach czterdziestych - pięćdziesiątych XV wieku kronikarz stosował nomenklaturę czasów sobie współczesnych, gdy Oliverę rzeczywiście tak określano, a małżonką panującego wówczas sułtana Murada II była kolejna Serbka, tym razem rzeczywista despotówna.

Bazując głównie na kronice Szarafa ad Dina, a właściwie jej mało precyzyjnym siedemnastowiecznym francuskim tłumaczeniu, uznano informacje pochodzące $z$ europejskich źródeł za wielce wątpliwe, podkreślając, że Bajezid i jego rodzina traktowani byli przez Tamerlana z pełnym szacunkiem ${ }^{23}$. Jednak tak krytykowane informacje Konstantego z Ostrovicy, Leunclaviusa czy Orbiniego znajdują potwierdzenie w źródłach wschodnich i to pierwszorzędnych. Do takich należy niewątpliwie dzieło Ibn Arabszacha Dziwy przeznaczenia, czyli opowieści o Timurze. Autor, z pochodzenia Syryjczyk, jako chłopiec trafił do niewoli wielkiego zdobywcy, a później przez wiele lat mieszkał i uczył się w Samarkandzie, niewątpliwie, więc, wiele wydarzeń znał i pamiętał z autopsji. Był też człowiekiem bardzo wysoko wykształconym i bywałym w świecie ${ }^{24}$. Swoją pracę na temat Timura napisał w roku 1436 . Nie jest to zresztą ani typowa kronika, ani typowa biografia, intencją autora było raczej pokazanie osobowości Timura. Wzajemne relacje między zwycięzcą a zwyciężonym znakomicie się nadawały do tego typu przedstawień.

W świetle relacji Ibn Arabszacha Tamerlan z jednej strony ceremonialnie okazywał wielki szacunek Bajezidowi, z drugiej strony jednak naigrawał się z niego. Między innymi pewnego razu zaprosił go na ucztę w towarzystwie kobiet. Było ciemno, dlatego dopiero po pewnym czasie zaproszony jeniec zorientował się, że kobietami, z którymi się zabawiano, były jego własne żony i nałożnice. Miała to być zemsta Tamerlana za to, że wcześniej w jednym ze swoich listów Bajezid odgrażał mu się, że będzie świętował swe zwycięstwo z jego żonami ${ }^{25}$. Wydarzenie to miało bezpośrednio wpłynąć na depresję i gwałtowne pogorszenie się stanu zdrowia Bajezida, u którego odezwały się wszystkie dawne przypadłości i pootwierały się dawne rany. Ibn Arabszach potwierdza także te informacje, które mogą wydawać się najbardziej fantastyczne, mianowicie o zamknięciu Bajezida w ostatnim okresie życia do żelaznej klatki i jego śmierci w niej na oczach Tamerlana, objaśniając, że Tamerlan miał wozić pokonanego przeciwnika w żelaznej klatce dlatego, że tak samo on niegdyś postapił ze zwyciężonym Szapurem ${ }^{26}$. Możliwe też, że był to środek zapobiegawczy przed ewen-

23 Н. Гиљен, О. Шарановић, С. Јовићевић Јов, Приниеза Оливера, заборављена српска Кнегиња, S. 102-103.

24 Biografia Ibn Arabszacha zob. R. D. McChesney, A Note on the Life and Works of Ibn 'Arabshāh, w: History and Historiography of Post-Mongol Central Asia and the Middle East. Studies in Honor of John E. Woods, Wiesbaden 2006, s. 205-249.

25 Ибн Арабшах, История амира Темура, Ташкент 2007, s. 188.

26 Tamże, s. 196. Interesujące, że Marian Małowist, który także korzystał z ibn Arabszacha, lecz w wydaniu angielskim, stwierdził, że informacje o trzymaniu Bajezida przez Timura w żelaznej klatce nie mają pokrycia w źródłach - M. Małowist, Tamerlan i jego czasy, Warszawa 1991, s. 76. 
tualną ucieczką Bajezida w czasie podróży. Wygląda też na to, że sytuacja Bajezida i jego rodziny w niewoli pogarszała się, w miarę jak pogarszała się sytuacja państwa osmańskiego, które pogrążone w chaosie wojny domowej utraciło kontrolę nad większością swych prowincji w Azji Mniejszej.

Śmierć Bajezida znów zmieniła jednak sytuację i większość jego najbliższych została z niewoli wypuszczona. Wśród nich znalazła się również Olivera, która jeszcze w 1403 roku wróciła do Serbii. Zdaniem niektórych badaczy wypuszczenie jej z niewoli było związane z polityczną woltą jej brata, Stefana Lazarevicia, który zbliżył się do Bizancjum, znajdującego się w dobrych stosunkach z Tamerlanem. Nie jest jasne czy Olivera została uwolniona za okupem czy bez. Żyła jeszcze w Serbii przez ponad czterdzieści lat, ciesząc się dużym szacunkiem. Przez wiele lat mieszkała w Belgradzie, a po śmierci brata i przekazaniu tej twierdzy Węgrom, przeniosła się prawdopodobnie na dwór swego siostrzeńca, Jerzego Brankovicia w Smederewie. I tu jednak nie mogła zatrzymać się długo, gdyż w 1439 roku Smederewo zostało na 5 lat zajęte przez Turków. Nie wiadomo gdzie mieszkała w ostatnich latach swego życia, często podróżowała, zwłaszcza do Dubrownika. Utrzymywała bliskie kontakty z siostrą Jeleną Balšić 2 do voto Hrvatinić. Jelena umierając w 1442 roku zapisała jej w testamencie ikonę oprawną w złoto i perły oraz 200 dukatów, które miały być przeznaczone na wspomnienie jej duszy oraz sieroty. W dniu 9 lipca 1443 roku pełnomocnik Olivery, Radivoj Šiglic, odebrał rzeczy zapisane jej przez siostrę ${ }^{27}$. Jest to ostatnie świadectwo na temat Olivery jako osoby żyjącej. Miała wówczas około 71 lat. Zmarła prawdopodobnie krótko po tej dacie, nie wiadomo gdzie, nie wiadomo też gdzie została pochowana ${ }^{28}$.

Walka o władzę w państwie osmańskim po bitwie ankarskiej spowodowała, że chrześcijańscy sojusznicy stali się dla licznych synów Bajezida bardzo pożądani. Pierwszym, który szczególnie blisko związał się z chrześcijanami był Sulejman. Zrezygnował on $\mathrm{z}$ oblężenia Konstantynopola prowadzonego przez 10 lat przez jego ojca, zwrócił Bizantyńczykom niektóre tureckie zdobycze, między innymi Thessalonikę, uczynił europejski Adrianopol stolicą swego państwa, nie rezygnując jednak z walki o Brusę przy pomocy europejskich głównie sojuszników. Sojusz Sulejmana z Bizancjum w 1409 roku przypieczętowany został jego małżeństwem z krewną cesarza. Według Leonika Chalkokondylesa miała ona pochodzić z genueńskiego rodu Doria ${ }^{29}$. Bardziej prawdopodobna wydaje się jednak informacja dobrze zorientowanego w rodzinnych koligacjach Paleologów Georgiosa Sphrantzesa, że była to córka despoty Morei, Teodora I Paleologa ${ }^{30}$. Niestety, nic konkretnego o niej nie wiemy. Zapewne po zamordowaniu męża przez brata Musę w lutym 1411 r. powróciła do Konstantynopola. Nie wiadomo czy miała dzieci. Z pewnością nie był jej

${ }^{27}$ Н. Гиљен, О. Шарановић, С. Јовићевић Јов, Принцеза Оливера, заборављена српска Кнегиња, s. 204.

${ }^{28}$ С. Новаквић, Срби и Турии XIV и XV века, Београд 1968, s. 298-301; Н. Гиљен, О. Шарановић, С. Јовићевић Јов, Принщеза Оливера, заборављена српска Кнегиња, s. 186.

${ }^{29}$ L. Chalcocondil, Expuneri istorice, s. 114.

${ }^{30}$ G. Sphrantzes, Memorii 1401-1477, Bucureşti 1966, s. 227. 
synem syn Sulejmana, Orchan, który przy pomocy bizantyjskiej podjął po śmierci ojca walkę o władzę, został jednak schwytany przez Musę i oślepiony ${ }^{31}$. Niewykluczone natomiast, że jej potomkiem w pierwszym lub drugim pokoleniu był inny Orchan, zamieszkujący w Bizancjum w połowie XV stulecia - bezpośrednia przyczyna konfliktu, który doprowadził do zdobycia Konstatntynopola przez Mehmeda II $^{32}$.

Musa, mniej więcej w tym samym czasie, co Sulejman, a może nieco wcześniej, ożenił się z córką hospodara wołoskiego Mirczy Starego. Uroczyste zaślubiny poprzedziły ścisły sojusz polityczny Musy z Mirczą, który umożliwił temu pierwszemu podjęcie walki o panowanie w państwie osmańskim ${ }^{33}$. Nie znamy imienia tej córki Mirczy, nie wiemy też, jakie były jej losy po klęsce i śmierci małżonka, zapewne wróciła do rodzinnego domu, podobnie jak druga chrześcijańska małżonka Musy, również nieznana z imienia, naturalna córka Carlo Tocco, władcy Kefalinii i części terytoriów albańskich. Ojciec jej, po zwycięstwie Musy nad Sulejmanem, sam począł intensywnie zabiegać o względy zwycięzcy, oferując mu rękę swej córki, a gdy ten został jego zięciem, korzystał z protekcji tureckiego pretendenta. Oczywiście tak długo, jak długo Musie udało się utrzymać przy władzy i życiu. Czy małżeństwo to miało charakter kontraktowy trudno powiedzieć, nie mamy dostatecznych wiadomości na ten temat. Żadna ze stron nie mogła wówczas pochwalić się na tyle silną pozycją, by dyktować warunki. Najprawdopodobniej córka Carla Tocco, jako małżonka Musy, przeszła na islam. Po śmierci pierwszego męża, córkę Carla Tocco wydano ponownie za mąż za Hamzę paszę, pozostała więc w środowisku islamskim ${ }^{34}$.

Ostateczny zwycięzca w walce o tron osmański, Mehmed I, współpracował głównie z państwami azjatyckimi, dlatego też zapewne, jako jedyny z wczesnych władców tego państwa, nie zawierał małżeństw z chrześcijankami. Jego syn i następca Murad II powrócił do aktywnej polityki europejskiej, jednym z elementów tej polityki było małżeństwo z chrześcijanką Marą Branković. Cztery jego małżonki Amina Hatun, Yeni Hatun, Hüma Hatun, Tacunissa Halime Hatice Hatun były córkami lokalnych władców małoazjatyckich i muzułmankami od urodzenia ${ }^{35}$, aczkolwiek istnieją wątpliwości czy wszystkie one były rzeczywiście oficjalnie poślubione. Największe wątpliwości w tym względzie budzi Hüma Hatun, matka Mehmeda II, która nie była kobietą wysokiego rodu. Mara była jedyną chrześcijanką poślubioną przez Murada, a także najprawdopodobniej najmłodszą jego małżonką. Dojście do skutku tego mał-

31 Tamże; L. Chalcocondil, Expuneri istorice, s. 117.

32 D. M. Nicol, Konstantyn XI ostatni cesarz Bizancjum, tłum, i komentarz M. Dąbrowska, Gdańsk 2004, s. 50-51.

33 M. Neşri, Djihanumma. Tarih-i al-i Osman, w: Cronici turceşti privind Țările române, vol. 1, ed. M. Guboglu, M. Mehmed, Bucureşti 1966, s. 115.

34 D. M. Nicol, The Despotate of Epiros 1267-1479: A Contribution to the History of Greece, Cambridge 1984, s. 181-182 - http://books.google.com 1208 2011; E. Zachariadou, Les Tocco: seigneurs, vassaux, otages, renegats, “Gamer”, 1, 1(2012), s. 13-14 - http://dergiler.ankara.edu.tr/dergiler/66/1680/ 17909.pdf.

${ }^{35}$ A. Akgündüz, S. Oztürk, Ottoman history: Misperceptions and Truths, s. 84. 
żeństwa podyktowane było przede wszystkim trudną sytuacją Serbii i nastapiło najprawdopodobniej z inicjatywy serbskiej.

Nagła bezpotomna śmierć despoty Stefana Lazarevicia w lutym 1427 roku postawiła państwo serbskie w niezwykle trudnej sytuacji. Wprawdzie zmarły despota już znacznie wcześniej desygnował na swego następcę siostrzeńca - Jerzego Brankovicia, który zresztą będąc wówczas jedynym żyjącym dorosłym męskim potomkiem Lazara nie miał wewnątrz kraju konkurentów, zmuszony był jednak pozyskać akceptację sąsiednich potęg i kontynuować trwającą wojnę z Turcją. Przychylność Węgier pozyskano jeszcze za życia Stefana Lazarevicia, zawierając porozumienie w tej sprawie. Obejmując rządy Jerzy Branković, zgodnie z umową w Tacie, zwrócił Węrom Belgrad i kilka innych twierdz, które jego poprzednik otrzymał od Zygmunta Luksemburczyka. Wprawdzie dostał za to inne wielkie majętności na Węgrzech, jednak granice despotowiny zostały poważnie uszczuplone, a co więcej, odpadł od niej Belgrad, pełniący funkcję drugiej stolicy. Jeszcze większe straty ponieśli Serbowie na południu. W chwili śmierci Stefana Lazarevicia wojska Murada II oblegały ostatnią większą twierdzę, jaka pozostała jeszcze w rękach serbskich - Novo Brdo. Wkrótce w wyniku zdrady dostała się w ręce tureckie twierdza Golubac, położona w północno-wschodniej części kraju, a wojna o nią, podjęta przez Węgry, zakończyła się niepowodzeniem. Dla Serbii oznaczało to znaczne rozciagnięcie frontu wojny z Turcją Osmańską i oskrzydlenie z dwóch stron. W 1428 roku Turcy opanowali Kruševac. Państwo serbskie praktycznie pozbawione zostało twierdz, a jego władca - stolicy.

Cała ta sytuacja zmusiła nowego despotę serbskiego do nawiązania negocjacji pokojowych z Muradem II. Warunki pokoju były tym razem bardzo ciężkie dla Serbii, która obciążona została podwyższonym haraczem (z 40000 do 50000 florenów rocznie) przy znacznie zmniejszonym terytorium i podporządkowana politycznie władcy osmańskiemu. Jedyne, co udało się Brankoviciowi wynegocjować, to zgoda na budowę nowej siedziby, co pozwoliło mu w krótkim czasie zbudować Smederevo ${ }^{36}$. Ceną za tę zgodę miało być małżeństwo jego starszej córki, Mary, z Muradem II.

W 1428 roku, gdy zawierano to porozumienie ${ }^{37}$, była ona jednak za młoda na małżeństwo (urodziła się prawdopodobnie ok. 1418 r.), a rodzice też nie spieszyli się z oddaniem córki. Pięć lat później Murad począł wyraźnie nalegać na realizację umowy, ale i tym razem jeszcze skończyło się na uroczystych zaręczynach. Dopiero 4 września 1436 roku odbyła się w Smederewie uroczystość zaślubin ${ }^{38}$. Najdokładniejszy opis tego wydarzenia dał kronikarz osmański z XV stulecia Aşik Paşazade:

Syn Wilka ${ }^{39}$ usłyszawszy to, ponownie wysłał posła z licznymi podarunkami. Ponadto powiedział: „Posag mojej córki jest przygotowany, przyślij ludzi, aby odprowadzili Twoją niewolnicę”. Pasza

36 М. Спремић, Деспот Бурађ Бранковић и негово доба, Београд 1999, s. 140.

${ }^{37}$ M. St. Popović, Mara Branković. Eine Frau zwischen dem christlichen und dem islamischen Kulturkreis im 15 Jahrhundert, Mainz und Ruhpolding 2010, s. 35-36.

${ }^{38}$ L. Stojanović, Srpski rodoslovi i letopisi, Glasnik Srpskog Učenog Društva, 53, Beograd 1883, s. 85.

${ }^{39}$ Vılkoğlu - syn Wilka, tak kronikarz nazywa Jerzego Brankovicia, syna Vuka Brankovicia. 
spotkał się z posłem i uznając sytuację pasza powiedział do padyszacha: „Panie trzeba odebrać”. Padyszach także powiedział: „Niech tak się stanie”. Wreszcie wysłał do Ishak Beya ze Skopja, Hadım Reyhan agę i Özbek agę. Liczni ludzie przybyli z nimi do Skopje. Następnie udali się we właściwe miejsce, do Smedereva. Gdy pozostawało im kilka dni drogi, syn Wilka wysłał im naprzeciw drużby niewiernej księżniczki. Niezwykła gościnność i godne wesela przysmaki zjednoczyły ludzi w Smederevie. Po tym, jak przyniesiono wspaniałe przysmaki z kuchni, policzono posag i dano spis Özbek adze. Syn Wilka powiedział: „Tego posagu nie daję mojej córce, lecz w całości daję go padyszachowi. Jeśli on zechce może dać go swojej niewolnicy, a jeśli zechce może także dać go innym niewolnicom".

Krótko potem jego córka pojechała do padyszacha do Adrianopola. Gdy sułtan przybył do Adrianopola nie świętował żadnego wesela. Nawet powiedział: „Mam robić wesele dla córki płacącego daninę niewiernego sipahiego?" Gdy doniesiono padyszachowi, co syn Wilka powiedział odnośnie posagu, powiedział: „Jak mógłbym zabrać sobie posag jego córki i oddać go innym moim niewolnicom, jeśli nie mam odpowiedniego podarunku dla mojej niewolnicy?” Nic nie wziął i oddał cały posag panny młodej z powrotem. Przez chwilę zatrzymał ją u siebie, ale potem odesłał ją do Brusy, Padyszach natomiast powrócił do Adrianopola ${ }^{40}$.

Trudno powiedzieć jak dalece informacje tureckiego kronikarza, piszącego pół wieku po tych wydarzeniach, odzwierciedlały rzeczywistość. Jak wynikałoby z tego przekazu, początki małżeństwa Mary były trudne. Raczej nie wzbudziła ona zainteresowania męża jako kobieta. Murad traktował małżeństwo z nią wyłącznie w kategoriach politycznych, przynajmniej na początku. Nie jest też jasne, czy posag, który Branković miał oddać do wyłącznej dyspozycji sułtana, był istotnie jedynym zabezpieczeniem dla jego córki. Inne źródła, o których niżej, zdają się świadczyć o tym, że nie. W każdym razie Murad wydawał się zaskoczony decyzją teścia, uznał jednak, że przyjęcie tego posagu oznaczałoby dla niego obowiązek zabezpieczenia żony majątkiem podobnej wartości, a na to nie był przygotowany. Niezależnie jednak od tego, czy małżonka sułtana dysponowałaby swoim posagiem, czy też wianem otrzymanym od męża istotne jest to, że miała możliwość samodzielnego dysponowania tym majątkiem.

Bardziej wiarygodne, bo współczesne źródło, stanowi relacja Jana Stojkovicia z Raguzy. Pisał on, że despotówna otrzymała ogromny posag w wysokości nie mniejszej niż 400000 dukatów w pieniądzach oraz przedmioty osobiste i środki na utrzymanie dworu o wartości nie mniejszej niż 200000 dukatów, nie licząc podarunków

40 Dostępne mi były dwa teksty tego fragmentu kroniki. Pierwszy - to uwspółcześniony tekst turecki (Aşik Paşazade, Osmanoğulları'nın Tarihi, ed. K. Yavuz, M. A. Yekta Saraç, Istanbul 2003, s. 194), trudno zrozumiały, zdaniem specjalistów z licznymi opuszczeniami i błędami. Drugi - to wydanie niemieckie Richarda Kreutela (R. F. Kreutel, Vom Hirtenzelt zur Hohen Pforte. Frühzeit und Aufstieg des Osmanenreiches nach der Chronik ,,Denkwürdigkeiten und Zeitläufte des Hauses „, Osman “ von Derwisch Ahmed, genannt Aşik - Paşa - Sohn, Graz - Wien - Köln 1959, s. 169-170), znacznie łatwiejsze do zrozumienia, jednak w porównaniu z tekstem tureckim zawiera ono liczne uproszczenia i opuszczenia całych fragmentów tekstu. Dlatego też za podstawę przyjęłam, mimo całej jego niedoskonałości, tekst turecki, posiłkując się miejscami tekstem niemieckim i korzystając z pomocy prof. Henryka Jankowskiego, za którą Mu serdecznie dziękuję. 
dla urzędników tureckich ${ }^{41}$. Dubrownicki dominikanin obawiał się, że dzięki posagowi serbskiej małżonki Murad II zdoła podbić Europę. Oczywiście, jeśli wierzyć temu, co pisał Aşik Paşazade, że sułtan zrezygnował z posagu, te obawy uznać by należało za nieuzasadnione, jednak nie do końca. Później, gdy już jako wdowa Mara wracała do kraju, zwrócone zostały Serbii dwa okręgi Toplica i Dubočica. Najczęściej interpretowano to w ten sposób, że były to ziemie, które sułtanka otrzymała w posagu. Jednak autor najnowszej i niewątpliwie najlepszej monografii na temat Mary, Mihajlo St. Popović, zwrócił uwagę na to, że ziemie te znajdowały się w rękach tureckich jeszcze na kilka lat przed małżeństwem despotówny i że znajdowały się tam ważne ośrodki kultu chrześcijańskiego ${ }^{42}$. W tym kontekście wydaje się bardziej prawdopodobne, że terytoria te stanowiły $\mathrm{w}$ istocie nie posag, lecz wiano sułtańskiej małżonki, a to z kolei mogłoby znaczyć, że przynajmniej część posagu Mary trafiła ostatecznie w ręce Murada II zwłaszcza, że z czasem jej relacje z mężem znacznie się ociepliły.

Jednym z elementów kontraktu małżeńskiego, niezależnie czy był on spisany, czy tylko ustny, była kwestia wiary. Podobnie jak jej chrześcijańskie poprzedniczki, Mara mogła zachować swą wiarę i była aktywna w sprawowaniu opieki nad chrześcijańskimi sanktuariami na terenie Turcji Osmańskiej. Dla Murada, który bardzo poważnie traktował ideę świętej wojny za wiarę, też musiała to być sytuacja trudna. Zupełnie nie wiemy, jak rozwiązywano te kwestie od strony ceremoniału religijnego. Wiadomo, że zarówno Mara, jak wcześniej Olivera wychodziły za mąż przy pełnej akceptacji cerkwi, która nie mogła ich nakłaniać, by żyły w grzechu. Można więc przypuszczać, że przed ich wyjazdem odbywała się jednostronna religijna ceremonia zaślubin. Zapewne ten fakt, jak też wesele wyprawione Marze przez ojca, mogły mieć wpływ na rezygnację Murada z uroczystości weselnych, zwłaszcza, że islam ich nie wymaga ${ }^{43}$. Z drugiej strony jednak niektórzy kronikarze bizantyńscy, jak np. Dukas, wbrew temu, co pisał dziejopis turecki, wspominają o uroczystościach weselnych Mary także w Adrianopolu. Panna młoda miała przybyć tam w towarzystwie dwóch swoich braci Grzegorza (Grgura) i Stefana. Po zakończeniu uroczystości, Grzegorza obdarowano i odesłano do ojca, Stefan natomiast pozostał jeszcze przez wiele lat, jako zakładnik ${ }^{44}$.

Choć często pisano później, że ojciec musiał oddać córkę w niewolę, to jednak nie należy tego rozumieć dosłownie. Mara nie była niewolnicą w haremie i nie była w nim zamknięta, choć mogła tam też okresowo pomieszkiwać. Oczywiście miała wolności tyle, ile mogła mieć kobieta zamężna wysokiego rodu w świecie islamskim, ale też przecież, jako chrześcijanka nie podlegała wszystkim prawom szarijatu.

41 Jan z Raguzy, Konstantynopol, 17. 11. 1436 - J. D. Mansi, Sacrorum conciliorum nova et amplissima collection, vol. 29, Paris 1904 (Graz 1961), s. 664 i inne wydania - cyt. za M. St. Popović, Mara Branković, s. 52-53.

42 M. St. Popović, Mara Branković, s. 62-63.

43 Nie znaczy to jednak, że takie uroczystości się nie odbywały. Np. uroczystości z okazji pierwszego małżeństwa Mehmeda II, wyprawiane przez tegoż Murada I, trwały ponad dwa miesiące.

44 Ducas, Istoria turco-bizantina 1341-1462, Ed. V. Grecu, Bucureşti 1958, s. 258-260. Dukas pisze wprawdzie, że obaj bracia Mary zostali odesłani do kraju, skądinąd wiemy jednak, że Stefan pozostał. 
Najprawdopodobniej miała własny dwór, na utrzymanie którego otrzymała środki od ojca, a zapewne też własny dom lub domy. Utrzymywała kontakt z braćmi, prowadziła korespondencję z ojcem.

Laonik Chalkokondyles twierdził, że piękna i inteligentna Mara rychło pozyskała miłość i szacunek małżonka, a także miała na niego duży wpływ. Jeśli istotnie tak było, to był to jednak dość długi proces pozyskiwania względów męża i umacniania pozycji na jego dworze. Niewątpliwie na przebieg jej związku z Muradem musiały wpływać skomplikowane stosunki serbsko-tureckie. A początkowo układały się one źle. Zaledwie niecałe dwa lata po zawarciu małżeństwa doszło do ostrego konfliktu między ojcem a mężem Mary. Jego przyczyna nie jest do końca jasna. Jeśli wierzyć Konstantemu z Ostrowicy głównym powodem konfliktu miało być wybudowanie w Smederewie nie mieszkalnego zamku i klasztoru, jak przewidziano w umowie, lecz fortecy ${ }^{45}$. Na to nałożyła się jednak jeszcze niezbyt udana kampania Murada II prowadzona przeciw Węgrom w roku 1438 i odmowa despoty osobistego przybycia na dwór sułtana, na który został wezwany. Niewykluczone, że córka powiadomiła go o zamiarze aresztowania, jak to stało się w przypadku wezwanego równocześnie hospodara wołoskiego Włada Dracula ${ }^{46}$. Nie udało jej się jednak zapobiec atakowi Murada II na Serbię i opanowaniu przez niego w 1439 roku Smederewa oraz całej niemal despotowiny. Musiało to odbić się na jej sytuacji. Kontakty Mary ze światem zewnętrznym zostały ograniczone, nie mogła widywać się z braćmi Grzegorzem i Stefanem, którzy znajdowali się w rękach jej męża. Nie udało jej się zapobiec oślepieniu w 1441 roku braci, których przyłapano na utrzymywaniu potajemnej korespondencji z ojcem ${ }^{47}$. Odegrała natomiast Mara ważną rolę w zainicjowaniu rozmów pokojowych między Turcją a Węgrami w roku 1444, nawiązując za pośrednictwem bazyliańskiego mnicha kontakt $\mathrm{z}$ ojcem i zapraszając do podjęcia mediacji ${ }^{48}$. Warto przypomnieć, że Murad II zaproponował wówczas Węgrom bardzo korzystne warunki pokojowe, a Jerzemu Brankoviciovi zwrócił z powrotem opanowane wcześniej ziemie serbskie. Jeszcze większym sukcesem była zgoda na utrzymanie przez Brankovicia tych ziem, mimo zerwania pokoju przez Węgry. Wypuszczeni też zostali wówczas na wolność oślepieni bracia Mary: Grgur i Stefan.

Mara nie miała z Muradem żadnego potomstwa i nigdy nie była w ciąży, co skłoniło niektórych do przypuszczeń, że małżeństwo nie zostało skonsumowane ${ }^{49}$. Jak

45 Pamiętniki janczara, s. 51.

46 V. Ciocîltan, Intre sultan şi împărat: Vlad Dracul în 1438, Revista de istorie, 29, 1976,11, s. $1767-$ -1770 .

47 Według Konstantego z Ostrovicy Mara dowiedziała się o rozkazie oślepienia braci już po jego wydaniu. Natychmiast udała się do męża i zdołała go przekonać, by zmienił zdanie i rozkaz odwołał. Murad II wysłał gońca z odwołaniem rozkazu oślepienia szwagrów, ten jednak przybył zbyt późno i rozkaz sułtana wykonano. Rozeźlony sułtan kazał za to pozbawić wzroku wykonawcę wyroku. - Pamiętniki janczara, s. 51-52.

48 Chronica Ragusina Restii item Joannis Gundulae, ed. S. Nodilo, Zagrabiae 1893, s. 289; M. Spremić, Despota serbski Jerzy Branković i bitwa pod Warnq 1444 roku, Balcanica Posnaniensia. Acta et studia, t. VIII, Poznań 1997, s. 41.

${ }^{49}$ G. Sphrantzes, Memorii, s. 358-359. 
było w rzeczywistości oczywiście nie wiemy, nie wiemy też, co było przyczyną bezpłodności Mary i jej generalnej niechęci do małżeństwa.

Georgios Sfrantzes podaje, że gdy po śmierci Murada zaproponowano jej małżeństwo z Konstantynem XI Paleologiem, późniejszym ostatnim cesarzem bizantyńskim, miała podobno odpowiedzieć, że ślubowała nie wychodzić więcej za mąż, jeśli Bóg wyzwoli ją z pogańskiej niewoli ${ }^{50}$, mógł to być wybieg dyplomatyczny umożliwiający delikatną odmowę niechcianego małżeństwa. Mara była osobą bardzo religijną, przy tym jednak światową. Podobnie zachowała się, gdy kilka lat później próbowano ją wydać za mąż za głośnego kondotiera Jana Jískrę i w tym wypadku kategorycznie odmówiła $^{51}$. Niemniej jednak za bardzo trafną uznać należy uwagę M. Popovicia, że z propozycjami małżeńskimi zwracano się nie do samej Mary, lecz do jej rodziców, a Jerzy Branković w 1451 roku nie miał żadnego interesu w nawiązywaniu bliskiego związku z Bizancjum ${ }^{52}$.

Przebywając w pałacu sułtańskim Mara poznała inną żonę Murada, Hüma Hatun, matkę Mehmeda II. Po jej śmierci w 1449 roku została „matką zastępczą” późniejszego wielkiego Zdobywcy. Niektórzy wręcz uważali ją mylnie za matkę wielkiego sułtana. Do takiego stwierdzenia mógł skłaniać fakt, że relacje Mary i jej wychowanka były do końca życia bardzo dobre, można nawet zaryzykować twierdzenie, że była ona jedyną kobietą, którą Mehmed rzeczywiście szanował. W niektórych dokumentach określał ją grzecznościowo mianem „matki”, co jednak nie oznaczało matki biologicznej.

Natychmiast po śmierci męża Mara wróciła do rodzinnego domu, ten jednak bynajmniej nie okazał się oazą spokoju. Rodzinny konflikt był wprawdzie przytłumiony dopóki żył wiekowy Jerzy Branković, jednak natychmiast po jego śmierci, 24 grudnia 1456 r., ujawnił się głęboki rozdźwięk pomiędzy poszczególnymi członkami rodziny, która generalnie podzieliła się na dwa stronnictwa na tle tak politycznym, jak i majątkowym. Następca Jerzego, jego najmłodszy syn Lazar, był zwolennikiem aktywnej polityki wobec Turcji, prowadzonej w sojuszu z Węgrami, w czym wspierała go małżonka Helena Paleolog i brat Stefan. Ostrożność w polityce tureckiej doradzała wdowa po zmarlym despocie, Irina Kantakuzina, jej brat Tomasz Kantakuzen, swego czasu bardzo wpływowy na dworze serbskim, Mara oraz jej najstarszy brat ślepy Grzegorz, który zresztą nie mógł się pogodzić z odsunięciem go od tronu. Nowy władca serbski próbował wywierać presję na matkę, by ta oddała mu cały ojcowski majątek i jak się wydaje był to najpoważniejszy powód sporu rodzinnego ${ }^{53}$.

Po nagłej śmierci Iriny Kantakuziny, której przyczynę upatrywano w otruciu, członkowie jej stronnictwa poczuli się niepewnie i jeszcze tej samej nocy zdecydowali się na ucieczkę z kraju. Sułtanka-wdowa zwróciła się wówczas o pomoc do swego

${ }^{50}$ G. Sphrantzes, Memorii, s. 360-361.

51 Р. Ћук, Царица Мара, Историјски Часопис, 25-26, 1976-1978, s. 66-67; М. Спремић, Деспот Бурађ Бранковић, s. 493-494.

52 M. St. Popović, Mara Branković, s. 89.

53 G. Sphrantzes, Mетогіi, s. 109; М. Ласкарис, Византиске принцезе у средњевековној Србији, Београд 1927, s. 105-106. 
wychowanka. Mehmed II podarował jej kilka majętności na terenie Macedonii: Ezeba (Jeżewo), Marabintzion (Mravince) i Doxompus zamieszkałych niemal w 100\% przez ludność chrześcijańską, w których znajdowały się też ważne ośrodki kultu chrześcijańskiego, w tym siedziba biskupia ${ }^{54}$. Mara opiekowała się tymi ośrodkami i niewątpliwie wywierała wpływ na obsadę stanowisk cerkiewnych w Turcji Osmańskiej. Mehmed II konsultował z nią swą politykę personalną w odniesieniu do cerkwi, bez wątpienia jej poparciu zawdzięczał swe stanowisko patriarcha konstantynopolitański, Dionizy $^{55}$. Bardzo wiele zawdzięczają jej również athońskie monastery: Hilandar i św. Pawła. Wprawdzie autentyczność dokumentu, w którym zapisywała ona na rzecz tych klasztorów daninę, jaką płacił Serbii Dubrownik za Ston, jest sprawą dyskusyjną ${ }^{56}$, to jednak faktem jest niewątpliwym, że klasztory te otrzymywały od Mary bardzo duże wsparcie, zapisała im praktycznie cały swój majątek. Klasztor św. Pawła otrzymał od Mary cenną relikwię cesarzy bizantyjskich Dary mędrców ze Wschodu. Przypuszcza się powszechnie, że relikwię tę Mara otrzymała od Mehmeda $\mathrm{II}^{57}$. Istnieje tradycja, że jako jedna z nielicznych kobiet została ona wpuszczona na Świętą Górę i odwiedziła serbskie klasztory, jednak jednoznacznych dowodów źródłowych na to, jak dotąd, nie ma. Aktywność Mary na polu religijnym była tak szeroka i jest oświetlona tak licznymi źródłami, że stanowi odrębny temat wykraczający poza ramy tego artykułu, temat zreszta poruszany przez licznych badaczy 58 .

Mara była też osobą aktywną politycznie. W latach 1469-1475 wraz ze swą siostrą Katarzyną hr. Cilly pośredniczyła w negocjacjach wenecko-tureckich ${ }^{59}$. Zmarła 14 września 1487 roku w swym majątku Jeżewie, gdzie też została pochowana ${ }^{60}$.

Ostatnim władcą osmańskim, który zawarł kontraktowy związek małżeński z chrześcijanką był Mehmed II. Według danych, podanych przez cytowanych już tu wielokrotnie A. Akgündüza, S. Oztürka, Mehmed II miał żenić się aż siedmiokrotnie, a żonami jego miały być: Gulbahar Hatun, Gulşah Hatun, Sitti Mukrime Hatun, Çiçek Hatun, Helena Hatun, Ana Hatun i Alexias Hatun. Trzy ostatnie były chrześcijankami: Helena była córką despoty Morei Dymitra Paleologa, Anna - córką cesarza

${ }^{54}$ M. Popović, Mara Branković, s. 122-127.

55 Tamże, s. 153-155.

${ }^{56}$ G. Jovanović, O poveli carice Mare od 15 aprila 1479 godine, Zbornik Matice srpske za filologiju i lingvistiku, 2007, vol. 50, бp. 1-2, s. 328. Autorka tego artykułu za R. Ćuk stoi na stanowisku autentyczności dokumentu.

57 Сава Хиландрац, Света Гора, Београд 1898, s. 281-282.

58 G. Ostrogorski, Komitisa i svetigorski monastiri, „Zbornik Radova Vizantološkog Instituta”, 13, 1971, s. 221-256; M. Živojinović, Komitisa u svetlosti novih dokumenta, „Zbornik Radova Vizantološkog Instituta", 41, 2004, s. 279-291; Р. Ћук, Царица Mapa, passim; A. Fotić, Despina Mara Branković and Chilandar: between the Desired and the Possible, w: Medjunarodni naučni skup Osam vekova Hilandara. Istorija, duhovni život, književnost, umetnost i architektura, red. V. Korać, Beograd 2000, s. 93-100; M. Popović, Mara Branković, s. 134-164 i in.

59 Bogaty materiał dokumentowy na ten temat $\mathrm{z}$ archiwów weneckich drukuje: M. Popović, Mara Branković, s. 165-190.

${ }^{60}$ F. Babinger, Z dziejów imperium Osmanów, s. 174. 
Trebizondy, a Alexias - księżniczką bizantyjską ${ }^{61}$. Jednak, jak się zdaje, mamy tu do czynienia z pomyłką.

Jedyną małżonką Mehmeda II, co do której mamy pewność, była poślubiona w 1460 roku siedemnastoletnia wówczas Helena, córka despoty Morei, Dymitra Paleologa i Teodory Asen. Poślubienie Heleny było jednym z warunków układu, na mocy którego Dymitr zdał się na łaskę Mehmeda II $^{62}$. Podobnie jak poprzedniczki, Helena pozostała przy chrześcijaństwie, mieszkała w odrębnym domu i miała własny dwór. Jak wykazują wcześniejsze przypadki, fakt odrębnego zamieszkania sułtańskich małżonek - chrześcijanek nie musiał oznaczać braku konsumpcji małżeństwa, aczkolwiek Franz Babinger sugeruje, że Mehmed II unikał kontaktu z Heleną w obawie, by ta nie podała mu trucizny ${ }^{63}$. Nic nie wiadomo na temat dzieci Heleny, która zmarła już w 1467 roku w czasie zarazy panującej w Stambule. Swoje klejnoty podarowała patriarchatowi konstantynopolitańskiemu. Śmierć Heleny oznaczała ustanie związków rodzinnych. Jeszcze w tym samym roku sułtan odebrał jej rodzicom liczne dobra, które im nadał wcześniej na wyspach Enos, Lemnos, Imbros, Thasos i Samotrake.

Do małżeństwa Mehmeda II z córką cesarza Trebizondy Dawida Komnena, Anną, nigdy ostatecznie nie doszło, choć jej ojciec w krytycznym momencie utraty państwa występował z taką propozycją. Rzekomą córkę cesarza bizantyńskiego, Aleksis, w ogóle trudno zidentyfikować z jakąkolwiek znaną skądinąd osobą z rodu Paleologów, a już tym bardziej z samym Bizancjum, biorąc pod uwagę fakt, że dwaj ostatni cesarze Jan VIII i Konstanty XI byli bezdzietni.

Konkludując:

W okresie kształtowania się Imperium Osmańskiego władcy osmańscy, podobnie jak władcy europejscy, uprawiali politykę matrymonialną zawierając kontraktowe małżeństwa polityczne także z córkami władców chrześcijańskich. Małżonki - chrześcijanki nie były na ogół zmuszane do przyjmowania islamu. Ich status ściśle określała zawarta przez męża z rodzicami lub braćmi intercyza, która zapewniała im prawo do zachowania religii, środki na utrzymanie własnych domów i dworów, a także zachowanie wysokiego statusu. Początkowo małżeństwa te, jak i związane z nimi stosunki rodzinne, traktowano bardzo poważnie i nie należy upatrywać w nich wyłącznie sposobu czy przejawu wasalizacji, najczęściej przynosiły one obustronne korzyści polityczne. Z czasem, w miarę pogłębiania się dysproporcji w możliwościach militarnych Turcji Osmańskiej i państw chrześcijańskich na Bałkanach, stawały się one elementem politycznego nacisku, nie oznaczało to jednak odchodzenia od zasad kontraktu. Likwidacja Bizancjum i państw bałkańskich spowodowała odejście sułtanów od polityki małżeństw kontraktowych z chrześcijankami, a później w ogóle rezygnację z małżeństw kontraktowych. Po opanowaniu Azji Mniejszej i Bałkanów straciły one całkowicie rację bytu.

\footnotetext{
${ }^{61}$ A. Akgündüz, S. Oztürk, Ottoman history: Misperceptions and Truths, s. 93.

${ }^{62}$ G. Sphrantzes, Memorii, s. 111-119.

${ }^{63}$ F. Babinger, Z dziejów imperium Osmanów, s. 187.
} 


\title{
CHRISTIAN WIVES \\ OF THE TURKISH SULTANS POLITICAL MARRIAGES IN THE OTTOMAN EMPIRE IN THE $14^{\text {th }}$ AND THE $15^{\text {th }}$ CENTURY
}

\begin{abstract}
Summary
During the formation of the Ottoman Empire, the Ottoman rulers, similarly to the European rulers pursued a policy of the matrimonial contract, when entering into political marriages with the daughters of the Christian rulers. Christian wives were not forced to convert to Islam. Their status was clearly defined by a marriage settlement signed by the parents or brothers of a future husband. This contract provided females with the right to retain their religion, their means of sustenance to maintain their homes and mansions, as well as high status. Initially, these marriages and the related family relationships were treated very seriously, and one should not consider them to be only a manifestation of vassalization, they usually brought mutual political benefits. With time, with growing disproportions in the military capabilities of the Ottoman Empire and the Christian states in the Balkans, they became a part of political pressure. This did not mean, though, a departure from the principles of marriage contracts. The abolition of the Byzantine Empire and the Balkan countries caused a withdrawal from the policy of the sultans' marriage contracts with Christian females, and later, a complete resignation from marriage settlements. After the conquest of the Balkans and Asia Minor, they lost their purpose.
\end{abstract}


